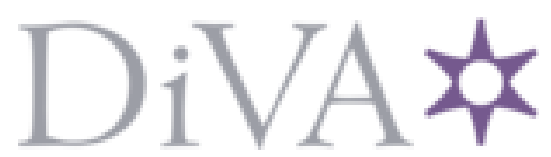

http://www.diva-portal.org

\title{
Preprint
}

This is the submitted version of a paper published in Worldviews on Evidence-Based Nursing.

Citation for the original published paper (version of record):

Hellström, A., Fagerström, C., Willman, A. (2011)

Promoting sleep by nursing interventions in health care settings: A systematic review.

Worldviews on Evidence-Based Nursing, 8(3): 128-142

http://dx.doi.org/10.1111/j.1741-6787.2010.00203.x

Access to the published version may require subscription.

N.B. When citing this work, cite the original published paper.

This is the pre-peer reviewed version of the following article: Hellström, A., \& Willman, A. (2011). Promoting Sleep by Nursing Interventions in Health Care Settings: A Systematic Review. Worldviews on Evidence-Based Nursing, 8(3), 128-142, which has been published in final form at http:// dx.doi.org/10.1111/j.1741-6787.2010.00203.x. This article may be used for non-commercial purposes in accordance with Wiley Terms and Conditions for Self-Archiving, http://olabout.wiley.com/ WileyCDA/Section/id-820227.html.

Permanent link to this version:

http://urn.kb.se/resolve?urn=urn:nbn:se:lnu:diva-42152 


\section{Promoting sleep by nursing interventions in health care settings. A systematic review}

\section{Short title: Promoting sleep by nursing interventions}

AUTHORS:

Amanda Hellström ${ }^{12 *}, \mathrm{RN}, \mathrm{PhD}$ Student

Cecilia Fagerström ${ }^{1}$, RN, PhD

Ania Willman ${ }^{1}$, RN, Professor

${ }^{1}$ Blekinge Institute of Technology, Karlskrona, Sweden.

${ }^{2}$ Department of Health Sciences, Lund University, Lund, Sweden

* Corresponding Author:

Amanda Hellström

Office: School of Health Science, Blekinge Institute of Technology, SE-371 79 Karlskrona, Sweden.

Telephone: +46455385463

FAX: +46 455385407

E-mail: amanda.hellstrom@bth.se 


\section{ABSTRACT}

Background: Sleep disturbances are a common problem among individuals in hospitals and institutions. Although several studies have explored this phenomenon, there is still a lack of knowledge about the effectiveness of sleep-promoting nursing interventions. This systematic review aims to describe and evaluate the effectiveness of sleep-promoting nursing interventions in health care settings. Design: A systematic review was performed. Method: In June 2009, a literature search was carried out in the following databases: Academic Search Elite, CINAHL, the Cochrane Library and MedLine/PubMed. Fifty-two references were identified and after critical appraisal nine studies were selected. A compilation of the results and the outcomes of the interventions were carried out. Further, the evidence strength of the interventions was assessed. Findings: Evidence for the nursing interventions sleep hygiene, music, natural sound and vision, stimulation of acupoints, relaxation, massage and aromatherapy, is found to be low or very low. Still large effects of interventions where found when using massage, acupuncture and music, natural sounds or music videos. The use of sleep hygiene and relaxation on the other hand showed only small effects. Conclusion: The paucity of studies implies that the confidence in the effects shown, and the lack of high evidence strength for many nursing interventions, most certain will change if further studies are carried out. The uncertainty about the effects calls for more research before implementing the interventions into clinical practice.

Keywords: evidence, inpatients, nursing home, nursing interventions, sleep and systematic review. 


\section{INTRODUCTION}

Sleep research has been ongoing for decades. However, the intention was to study the structure of sleep and the body's need of sleep in order to function. During the 1990s, the American Association of Critical Care Nurses highlighted sleep disturbances as a major issue and called for studies to explore effective methods for reducing such disturbances and promoting sleep (Evans \& French 1995). As part of the "Putting evidence into practice" project, Page et al. (2006) carried out a review investigating evidence-based interventions for sleep-wake disturbances in cancer patients, none of which received the highest recommendation for nursing practice. The authors pointed out that most of the studies had quasi-experimental or descriptive designs and that the use of instruments for measuring the outcome of the interventions was inconsistent (Page et al. 2006).

\section{Why nursing interventions}

Nursing interventions, as defined by the theorist Myra Levine, are actions founded on human interaction that relies on communication rooted in the organic dependency of one human being's relationships with other human beings. Also, the creation of an environment where health can occur is crucial (Wills 2007b). Virginia Henderson, another theorist, wrote that nursing is a way of caring for other humans in activities contributing to health or recovery (Wills 2007a). Persons in hospitals, hospice settings, nursing homes and other institutions are often fragile due to high age, chronic illness or severe diseases. To offer yet another pharmaceutical is not always beneficial to those persons. Nursing interventions based on the uniqueness of the patient, offering individualized care in close interaction with the patient might be a preferable alternative. 


\section{Background}

Morin et al. (1994) conducted a meta-analysis to examine the efficacy and durability of nonpharmacological treatments of a psychological nature for chronic insomnia and found that such methods led to improved sleep, especially in the areas of onset latency and sleep maintenance. Waking periods after sleep onset and total duration of sleep improved in treated patients but the differences were not statistically significant (Morin et al. 1994). Floyd et al. (2000) evaluated non-pharmacological interventions for sleep promotion in relation to three outcomes; sleep latency, frequency of waking after sleep onset and duration of time awake after sleep onset. Twelve interventions were identified and evaluated, of which cognitive and somatic relaxation, a quiet environment, bedtime routines, hot baths and sleep education appeared to be helpful (Floyd et al. 2000). Floyd et al. (2000) partly based their result on a previous meta-analysis (Morin et al. 1994) and we can but conclude that more research is required.

In 2007, Cheuk et al. conducted a systematic review that included studies with participants in outpatient clinics and pregnant women in order to investigate the safety and efficacy of acupuncture. Their findings suggested that acupuncture may improve sleep quality compared to a placebo (Cheuk et al. 2007).

The need of sleep

As far back as the days of Florence Nightingale, sleep was recognized as being beneficial to health and of great importance in nursing care due to its restorative function (Lane \& East 2008). Sleep deprivation causes impaired glucose tolerance and reduced insulin sensitivity. Also, the levels of Growth Hormone (GH) and cortisol, substances important for glucose 
metabolism, are altered, with lower levels of GH and higher levels of cortisol (Cauter et al. 2008). Moreover, persons suffering from insomnia are found to have higher levels at night of the peptide ghrelin, which stimulates appetite and hunger, which can cause metabolic disturbance (Motivala et al. 2009). The relationships between cell proliferation and sleep are not fully clear, but resent research suggests that sleep is essential for normal functioning and affect the neurogenesis indirect (Meerlo et al. 2009). Spiegel et al. (1999) accomplished a study where healthy, young adults (18-27 years) underwent sleep curtailment. The results of the study showed that after less than a week, there were conspicuous changes in metabolic and endocrine functioning. The changes implied increased risk of developing diabetes, hypertension and obesity. The insulin resistance and the increased levels of cortisol are similar to those seen in age-related diabetes. This indicates that the manifestations of sleep deprivation mimic some of the hallmarks of ageing (Spiegel et al. 1999).

\section{Causes of sleep disturbances in health care settings}

It is not uncommon for sleep disturbances and changes in sleep pattern to occur in connection with hospitalization (Ellis \& Dudley 1976, Murphy et al. 1977, Southwell \& Wistow 1995), especially among surgical patients (Tranmer et al. 2003).

Patients in medical and surgical units reported curtailment of sleep, not feeling refreshed by sleep, wakeful periods during the night and increased sleep during the day. The illness and stress of being hospitalized were found to be the causative factors (Humphries 2008). Other reasons for insufficient sleep in hospital may be an uncomfortable bed, being too warm, environmental noise, other patients and pain (Southwell \& Wistow 1995). The presence of intravenous catheters, a urinary catheter, drainage tubes and a gastric tube, which are 
common in postoperative patients, can also impair sleep (Edéll-Gustafsson et al. 1994). Increased daytime sleepiness, as a consequence of poor sleep at night, can imply decreased mobilization, complications related to inactivity and slower recovery from surgery (Knill et al. 1990). Edéll-Gustafsson et al. (2003) investigated subjective sleep quality in persons who had undergone coronary artery by-pass graft surgery (CABG). Almost $60 \%$ of the study population reported severe sleep disturbances (Edéll-Gustafsson et al. 2003). Recent research has indicated that postoperative sleep disturbances can last for months (Cremeans-Smith et al. 2006)or even years (Edéll-Gustafsson et al. 2003).

Another factor that disturbs patients' sleep is health care personnel routines. Dreher (1996) revealed that the sleeping pills are administrated late at night if at all and that the night nurse sometimes does not attend to the patients on her first round until after midnight. During the night the nurses are often noisy when doing their rounds and in their office, while the physician may prescribe blood samples to be taken in the small hours (Dreher 1996).

Hajak (2001) demonstrated that in most individuals, severe sleep disturbances occurred together with health problems, including stress, anxiety, accidents or hospital care. Sleep disturbances also impaired the subjective health-related quality of life (HR-QoL) when measured with the SF-36 questionnaire (Hajak 2001).

\section{Summary of background}

Previous research has revealed the harmful consequences of insufficient sleep and although the positive effects of sleep is somewhat hazy, it seems to be crucial for normal functioning and HR-QoL. Admittance to hospital or other health care settings often induces sleep 
deprivation and sometimes even persistent sleep disturbances. It is therefore of great importance to find efficient nursing interventions for sleep promotion in this environment. The aim of this systematic review is to describe and evaluate the effectiveness of sleeppromoting nursing interventions for patients in health care settings. In this study health care settings are defined as settings where persons are admitted over night. This includes hospital wards, nursing homes, and retreats for elderly persons and hospices.

\section{METHODS}

A critical appraisal and compilation of the documented research in the area of sleep promotion in health care settings was conducted.

\section{Literature search}

The literature search, which was inspired by Droogan and Cullum (Droogan \& Cullum 1998), was carried out in the Academic Search Elite, CINAHL, Cochrane Library and MedLine/PubMed databases. Searches were made by combining indexed terms from the thesauruses of these databases and free text using the Boolean operators "OR" and "AND". Initially a large number of search words were chosen. However, when combining them into search blocks, only a few combinations proved to be successful in identifying articles of interest for this review; namely sleep, music therapy, relaxation therapy, complementary therapies, sleep promotion, sleep management, intervention and experimental studies.

\section{INSERT Table 1. "Literature search"}

Studies on sleep promotion in health care settings written in English or a Scandinavian language, having experimental design or being systematic reviews or meta-analysis were included. Studies concerning shift workers, health care personnel, pharmacological 
treatment including herbal remedies as well as children ( $<19$ years) were excluded, as were studies that did not involve patients in health care settings.

References were identified and duplicates excluded. Those without an abstract were rejected. The abstracts of the remaining references were read and those that corresponded with the aim were selected. The primary search yielded 35 articles of interest, of which seven were reviews or meta-analyses. A bibliographic search revealed another 17 articles. Selected articles were read in their entirety and were restricted to the inclusion and exclusion criteria. Twenty-one articles remained for critical appraisal. Excluded articles and reasons for exclusion are presented in table 2 .

\section{Insert "excluded articles", table 2 here}

\section{Critical appraisal}

Templates from the Critical Appraisal Skills Programme (CASP) were used to evaluate scientific quality. The CASP was first launched in 1993 and aims to help individuals develop skills for identifying and making sense of research evidence. The CASP comes with a free down-load of appraisal tools (Public-health-resource-unit 1993). The full text documents were independently assessed by two of the researchers. If disagreement arose between the researchers, the reference was discussed until consensus was achieved. The scientific quality was judged as high, medium or low.

The CASP templates contained ten to eleven questions about, for example design, ethical considerations, drop outs, size of the study, its effect and relevance and the generalizability of the findings. The CASP templates do have specific questions but there is no scoring system, why it is up to the reviewer to put together the final decision about the scientific 
quality of a paper. The authors of this review decided to classify the studies into three levels of quality upon the critical appraisal. The level of quality was dependent on the elusiveness and reliability of the methods of the studies and the severity of the flaws in design or in the description. The grading was not limited to randomized, controlled trials (Willman et al. 2006), and for that reason the templates were found to be suitable. It is essential to have knowledge of the study's research design when assessing the effectiveness of an intervention.

\section{Assessment of evidence}

The GRADE system was used for compiling and assessing the evidence (Figure 1). It consists of a four-grade scale that offers a systematic approach to evaluate the quality of evidence and the strength of recommendations. Four key elements are of great importance to the reviewer, namely the design, quality, consistency and directness of the study (BritishMedical-Journal-Group 2004). Articles found to have medium to high scientific quality after the critical appraisal were included in the compilation and assessment of the evidence (Table 3). Those deemed to be of low scientific quality were excluded, which is a recommended procedure by the GRADE-group (British-Medical-Journal-Group 2004). The GRADE system have four different levels of strength of evidence; high indicates that further research is unlikely to change the confidence in estimated effects, moderate indicates that further research is likely to have an important impact on the confidence of the estimates of effects, low evidence implies that further research is very likely to impact the confidence in the estimates of effects and then very low evidence indicate that any estimates of effects are uncertain (British-Medical-Journal-Group 2004).

Insert Figure 1 “GRADE assessment” here 


\section{INSERT TABLE 3 “included articles” HERE}

\section{RESULTS}

Twenty-one articles were scrutinized with the CASP templates, of which nine fulfilled the scientific quality criteria medium or high (Table 3). The nine articles were sorted by intervention and are presented in the following categories: sleep hygiene; music, natural sounds and vision; stimulation of acupoints; relaxation; massage; and aromatherapy. The categories, together with the strength of evidence for each category, are presented in Table

4.

\section{INSERT Table 4 "Evidence strength of interventions" HERE}

Sleep hygiene

Sleep hygienic interventions aim to minimize factors that can disturb and disrupt sleep, both in the environment and on a personal level. Examples of such interventions are; the regulation of room temperature for increased comfort, control of light and noise levels during the night, avoidance of day-time napping, engaging in physical activity during the day, abstaining from the consumption of caffeine and alcohol at late hours and so forth. This systematic review identified two studies that investigated sleep hygienic interventions (Table 3). Sleep hygienic protocols are easy to apply, but there is uncertainty about the effect of the intervention. Alessi et al. (2005) showed no effects on total sleep time (TST), LaReau et al. (2008) showed only a small effect. No significant differences were observed concerning Mid Sleep Awakenings (MSA). Increased alertness during the day was also found in one of the studies (Alessi et al. 2005). Regarding the consistency of the results, different measurements were used in the studies, actigraph respectively a subjective self-rating questionnaire, which makes a compilation of the findings difficult. Due to the inconsistency in outcome measures 
and the fact that one of the studies (LaReau et al. 2005) was found to have medium scientific quality, the evidence for the intervention is found to be low. (Table 4).

\section{Stimulation of acupoints}

Acupuncture was examined in a study from Hong Kong (Suen et al. 2002) and the related auricular therapy in a study from Japan (Kim et al. 2004)(Table 3). Both studies were randomized controlled trials with medium scientific quality and Suen et al. (2002) is characterized as a large study. Measurements were made by means of an actigraph (Suen et al. 2002) or three self-rating scales (Kim et al. 2004). Stimulation of selected acupoints on the body had a positive effect on TST as measured with the Morning Questionnaire (Morgan et al. 1997) and a lower total scores on the Insomnia Severity Index(ISI) (Bastien et al. 2001) and Athens Insomnia Scale (AIS) (Soldatos et al. 2000). ISI describing the impact insomnia has on the person's daily life and AIS describing the symptoms of the sleep difficulties (Kim et al. 2004). Positive effects on SE (sleep efficiency), MSA and SL (sleep latency) was seen after stimulation of acupoints in the ear of primary insomnia patients, with large effect on the two first mentioned outcomes (Suen et al. 2002). Sleep-promotion by acupuncture requires familiarity with the technique and it is possible that patients find the intervention painful, as reported by Kim et al. (2004). The evidence for the intervention is very low, due to the different measurements that were used, and the scientific quality of the two studies (Table 3). However, the directness is found to be high, since the intervention is tested in different samples and in both primary (Suen et al. 2002) and secondary (Kim et al. 2004) insomnia (Table 4). 


\section{Massage}

Massage was the subject of two studies (Richards 1998, Soden et al. 2004), which were considered of medium scientific quality. The consistency of the results reported by Richards is high and measurements were made by polysomnography. The intervention showed large effect on SE and TST and small effect on SL and MSA (Table 4). Soden et al. (2004) showed positive effect on sleep score measured with the Verran \& Snyder-Halpern (VSH)-sleep scale (Snyder-Halpern \& Verran 1987), when giving back- massage to 13 patients with advanced cancer. The intervention has been tested in different categories of patients, both studies are well-designed, positive effects have been reported both in objective and subjective measurement but since the different approaches in outcome measures the studies cannot be compiled and the scientific quality of the studies were judged to be medium (Table 3 ). Therefore the evidence strength is found to be very low.

\section{Relaxation}

Different relaxation techniques to promote sleep have been evaluated by (Richards 1998, Richardson 2003). The intervention consisted of audio-taped instructions for relaxation, mental imagery and music, or oral relaxation instructions and mental imagery provided in person. Both studies were RCTs and of medium scientific quality (Richards 1998, Richardson 2003). The methods of measurement differed between the studies. Effects of the relaxation on sleep were small; still the intervention is tested only in intensive care and mostly in male patients. In summation, different measures have been used that makes compilation of the findings difficult, the settings used in the studies are similar (with a predominance of men in the Richards' study) which effects the directness. Considering both studies had medium scientific quality the evidence for the intervention is found to be very low (Table 4). 
Music, natural sound and vision

In the study by Zimmerman et al. (1996) patients listened to soothing music to facilitate relaxation or watched a VHS with instrumental music and views of different environments (Zimmerman et al. 1996). Williamson (1992) investigated the effects of common natural sounds, such as the surging sea, rain or the sound of a waterfall (Williamson 1992). Both Zimmerman et al. and Williamson described randomized, controlled trials, in which the assessments were based on the Richards Campbell Sleep Questionnaire (RCSQ) (Richards 1987) in patients who had undergone Coronary Artery By-pass Graft (CABG) surgery. Unfortunately the scoring is reported in different manors that makes compilation of the results hard, still both studies shows large effect of the intervention by significant differences in total score on RCSQ (Williamson 1992) and large effect sizes (Zimmerman et al. 1996). Especially watching music videos had a large effect. The directness of the intervention is high in patients who have undergone CABG-surgery, but for other categories of patients it is uncertain. The inconsistent data on RCSQ score, the limitation in directness of the intervention and that one study had medium scientific quality, render in very low evidence for the intervention.

\section{Aromatherapy}

Aromatherapy was investigated in one study (Soden et al. 2004), that had medium scientific quality. The procedure and design was thoroughly described but the sample size required for showing differences at $p$-value $<0.5$ with a power of 0.8 could not be reached. This was due to slow enrolment and poor health in many of the hospice residents (Soden et al. 2004). A description of the drop outs was also lacking. The efficacy of the intervention was not 
significant compared to control group. The evidence strength is found to be very low (Table 4).

\section{DISCUSSION}

\section{Main findings}

The aim of this systematic review is to describe and evaluate the efficacy of sleep-promoting nursing interventions for patients in health care settings. Evidence for the nursing interventions in this study is found to be low or very low, which indicate the need of further research. Still large effects of interventions where found when using massage, acupuncture and music, natural sounds or music videos, which is intriguing. The use of sleep hygiene, aromatherapy and relaxation on the other hand showed only small effects.

Zimmerman et al. (1996) and Williamson (1992) used music, common natural sounds and music videos to create calm and promote sleep. Both studies indicate that music and calming sounds promote sleep in the hospital environment. However, even if the intervention seems to have a large positive effect on sleep, the studies only concerned patients undergoing CABG-surgery, why this also needs to be tested in other settings and categories of patients.

Two studies in this review investigated the effects of acupoint stimulation in persons with insomnia (Kim et al. 2004, Suen et al. 2002). One point to consider however is that participants in the study (Suen et al. 2002) were diagnosed in accordance with traditional Chinese medicine. In studies undertaken in western countries the International Classification of Sleep Disorders (ICSD) (American-Academy-of-Sleep-Medicine 2005) is commonly used for 
diagnosis. Both studies did, however, describe positive effects of the intervention, indicating that techniques such as acupoint stimulation are useful for treating both primary and secondary insomnias.

Massage as an intervention for sleep promotion was only found in two studies. The Richards' study (1998) showed large effects of the intervention on sleep quality and total sleep time. The study was carried out in a veterans' hospital with only male patients in an intensive care ward. Soden et al. (2004) tested massage in patients with advanced cancer, the sample was small and had great difference in age $44-85$ years, yet positive effects were seen of the intervention. Since massage demands trained personnel and it can be somewhat time consuming, it is possible that it is only feasible in high density wards. Massage as sleep promotion, seems to be effective in severely ill patients.

Sleep hygienic advice seems to be a direct intervention that is easy to apply in different care settings and might even reduce the expenses of hypnotics. LaReau et al. (2008) showed that by adapting a sleep hygienic protocol the consumption of sleep medication could be lowered. Still the studies in this review could not show any statistical significant effect of sleep hygiene. The use of sleep hygienic protocols could be a good start in improving patients' possibilities of getting a good night's sleep, but the intervention is not enough to affect outcome measures. Also reports on difficulties in applying a sleep hygienic protocol exist (Schnelle et al. 1999) due to a great resistance among staff to its use. The controversy centred on fire code policy, violation of residents' rights and the negative reaction of staff members when asked to lower their voices. This displays a great fragility of using sleep hygienic protocols. It takes compliance of the entire working staff and that can be 
troublesome in larger units or wards or in places were substitutes or casual workers often are needed.

It is truly challenging to find a sleep-promoting intervention that can be implemented in various environments and patient categories. The setting and the patient category can be delimiting in what interventions that can be adopted. Nursing implicates that patients are seen as individuals with individual needs and certain flexibility is needed. Virginia Henderson (2006) describe the function of the nurse as meeting the patients health needs, to attain, retain and regain health and to take the role as the voice of the patient when the patient cannot stand up for him/herself. One fundamental need of the patient mentioned by Henderson is sleep. Henderson also emphasizes the individualized care that should be given and furthermore is part of the patient's rights (Hendersson 2006). In the health care setting, staff members not only have to take account of primary insomnias but also secondary insomnias caused by underlying illness and the environment. The former occur predominantly among elderly patients, often in combination with comorbidity, a large intake of medication, disturbances in the circadian rhythm and nocturia (Bliwise 1993, Stone et al. 2008). The most successful approach might be to tailor the interventions based on the individuals' needs and desires. However, to establish confident effects and evidence for such an approach, where several interventions are offered simultaneously, is problematic. Two of the excluded studies tried this (McDowell et al. 1998, Robinson et al. 2005), but failed since there were insufficient reports on how many that got a certain intervention and the outcomes were not reported. Further, were there no control groups and the sample sizes were to small when divided into several groups. 
When reviewing the articles presented in this review, a major concern was the lack of consistency in measurements between studies. Objective measures were found in three studies (Alessi et al. 2005, Richards 1998, Suen et al. 2002), of which one used polysomnography (Richards 1998), which is considered to be the reference standard (Onen et al. 2005). Six studies employed recognized rating scales such as the VSH-sleep scale, RCSQ and ISI (Kim et al. 2004, LaReau et al. 2008, Richardson 2003, Soden et al. 2004, Williamson 1992, Zimmerman et al. 1996). In one study the authors developed their own questionnaire and diary (Suen et al. 2002). All studies were RCTs, which is acknowledged as the most definitive way of evaluating the effectiveness of an intervention (Kazdin 1998). However, several of the excluded studies were also RTCs but flawed and judged to have low scientific quality (Table 2).

\section{Studies excluded from the compilation}

It can be debated whether or not it is right to exclude identified studies from a systematic review. However, it cannot be considered reasonable to include studies that are incompletely described or unsatisfactory in other ways when establishing evidence for nursing interventions. This procedure is also supported by the GRADE group (BritishMedical-Journal-Group 2004). The studies excluded from this review (Ancoli-Israel et al. 2002, Cmiel et al. 2004, Ho et al. 2002, Koyama et al. 1999, McDowell et al. 1998, Ouslander et al. 2006, Richards et al. 2003, Schnelle et al. 1999, Simeit et al. 2004, Smith et al. 2002, Walder et al. 2000) and the reasons for exclusion are presented in Table 2. 


\section{Limitations}

This systematic review has some limitations. One limitation concerns the scope of this review. Identifying studies of non-pharmacological interventions conducted in a nursing home or in-patient care facility restricted the area of interest. Despite the large number of studies that were eligible for scrutiny, only twenty-one were selected, and a mere nine passed the critical appraisal, which highlights how small this area is and the difficulties in conducting these intervention studies. Articles without an abstract were immediately rejected. It is possible that studies of importance were thereby excluded. Another limitation is that even when templates are followed, critical appraisal, compilation of interventions and the grading of evidence are subjective measures.

\section{CONCLUSION}

The effects of music, music video-watching or listening to natural sounds, getting a back massage or stimulation by acupuncture were large, considering sleep outcomes. Relaxation, aromatherapy and use of sleep hygienic advises/protocols showed small or no effect on sleep. Still only low or very low evidence could be established for all of the interventions presented in this review. The paucity of studies also implies that the confidence in the effects shown and the lack of high evidence strength for many nursing interventions, most certain will change if further studies are carried out. The uncertainty about the effects calls for more research before implementing the interventions into clinical practice. 


\section{REFERENCES}

Alessi, C. A., J. L. Martin, A. P. Webber, E. C. Kim, J. O. Harker \& K. R. Josephson. (2005). Randomized controlled trial of non pharmacological intervention to improve abnormal sleep/ wake patterns in nursing home residents. Journal of American Geriatric Society, 53, 803-810.

American-Acad em y-of-Sleep-Medicine. (2005). ICSD-2. International classification of sleep disorders. Diagnostic and coding manual. American Association of Sleep Medicine.

Ancoli-Israel, S., J. L. Martin, D. F. Kripke, M. Marler \& M. R. Klauber. (2002). Effect of light treatment on sleep and circadian rhythms in demented nursing home patients. Journal of A merican Geriatric Society, 50, 282-289.

Bastien, C. H., A. Vallières \& C. M. Morin. (2001). Valid iation of the Insomnia Severity Index as an outcome measure for insomnia research. Sleep Medicine, 2 , 297-307.

Bliwise, D. L. (1993). Sleep in normal ageing and dementia. Sleep, 16, 40-81.

British-Medical-Journal-Group. (2004). Grading quality of evidence and strength of recommendations. British Medical Journal group.

Cauter, E. v., K. Spiegel, E. Tasali \& R. Leproult. (2008). Metabolic consequences of sleep and sleep loss. Sleep Medicine, 9, S23-S28.

Cheuk, D. K. L., W. F. Yeung, K. F. Chung \& V. Wong. (2007). Acupuncture for in somnia (review). The Cochrane Library. John Wiley \& Sons.

Cmiel, C. A., D. M. Karr, D. M. Gasser, L. M. Oliphant \& A. J. Neveau. (2004). Noise control: a nursing team's approach to sleep promotion. American Journal of Nursing, 104, 40-48.

Cremeans-Smith, J. K., K. Millington, E. Sledjeski, K. Greene \& D. L. Delahanty. (2006). Sleep disruptions mediate the relationship between early postoperative pain and later functioning following total knee replacement surgery. Journal of Behavioral Medicine, 4, 215-222.

Dreher, H. M. (1996). Beyond the stages of sleep: an emerging nursing model of sleep phases. Holistic Nursing Practice, 10, 1-11.

Droogan, J. \& N. Cullum. (1998). Systematic review s in nursing. International Journal of Nursing Studies, 35, 13-22.

Edéll-Gustafsson, U., C. Arén, E. Hamrin \& J. Hetta. (1994). Nurses' notes on sleep patterns in patients undergoing coronary artery bypass surgery: a retrospective evaluation of patient records. Journal of Advanced Nursing, 331336.

Edéll-Gustafsson, U. M., G. Gustavsson \& P. Yngman-Uhlin. (2003). Effects of sleep loss in men and women with insufficient sleep suffering from chronic disease: a model for supportive nursing care. International Journal of Nursing Practice, 49-59.

Ellis, B. W. \& H. A. F. Dudley. (1976). Some aspects of sleep research in surgical stress. Journal of Psychosomatic Research, 20, 303-308.

Evans, J. C. \& D. G. French. (1995). Sleep and healing in intensive care settings. Dimen sions of Critical Care Nursing, 14, 189-199. 
Floyd, J. A., M. L. Falahee \& R. H. Fhobir. (2000). Creation and analysis of a computerized database of interventions to facilitate adult sleep. Nursing Research, 49, 236-241.

Hajak, G. (2001). Epidemiology of severe insomnia and its consequences in Germany. European A rchives of Psychiatry and Clinical Neuroscience, 251, 49-56.

Hendersson, V. (2006). The concept of nursing. Journal of Advanced Nursing, 53, 21-34.

Ho, S. C., T. K. S. Wong, P. L. Tang \& S. M. C. Pang. (2002). Nonpharmacologic sleep promotion: bright light exposure. Complementary Therapies in Nursing and Midwifery, 8, 130-135.

Humphries, J. D. (2008). Sleep disruption in hospitalized adults. Medsurg Nursing, 17, 391-395.

Kazdin, A. E. (1998). Research design in clinical psychology. Allyn \& Bacon: Boston.

Kim, Y. S., S. H. Lee, W. S. Jung, S. U. Park, S. K. Moon, C. N. Ko, K. H. Cho \& H. S. Bae. (2004). Intradermal acupuncture on Shen-Men and Nei-Kuan acupoints in patients with in somnia after stroke. The American Journal of Chinese Medicine, 32, 771-778.

Knill, K. L., C. A. Moote, M. I. Skinner \& E. A. Rose. (1990). Anesthesia with abdominal surgery leads to intense REM sleep during the first postoperative w eek. Anesthesiology, 52-61.

Koyama, E., H. Matsubara \& T. Nakano. (1999). Bright light treatment for sleep-wake disturbances in aged individuals with dementia. Psychiatry and Clinical Neuroscience, 53, 227-229.

Lane, T. \& L. A. East. (2008). Sleep disruption experienced by surgical patients in an acute hospital. British Journal of Nursing, 17, 766-771.

LaReau, R., L. Benson, K. Watcharotone \& K. Manguba. (2008). Examining the feasability of implementing specific nursing interventions to promote sleep in hospitalized elderly patients. Geriatric Nursing, 29, 197-206.

McDowell, J. A., L. C. Mion, T. J. Lydon \& S. K. Inouye. (1998). A nonpharmalogic sleep protocol for hospitalized older patients. Journal of American Geriatric Society, 700-705.

Meerlo, P., R. Mistlberger, B. Jacobs, C. Heller \& G. McGinty. (2009). New neurons in the adult brain: The role of sleep and consequences of sleep loss. Sleep Medicine Reviews, 13, 187-194.

Morgan, P. J., R. Chapados, F. F. Chung, M. Gauthier, J. W. Knox \& J. Le Lorier. (1997). Evaluation of zolpidem, triazolam, and placebo as hypnotic drugs the night before surgery. Journal of Clinical Anesthesia, 9, 97-102.

Morin, C. M., J. P. Culbert \& S. M. Schwartz. (1994). Nonpharmacological interventions for insomnia: a meta-analysis of treatment efficacy. American Journal of Psychiatry, 151, 1172-1180.

Motivala, S., J. Tomiyama, M. Ziegler, S. Khandrika \& M. Irwin. (2009). Nocturnal levels of ghrelin and leptin and sleep in chronic insomnia. Psychoneuroendocrinology, 34, 540-545.

Murphy, F., S. Bentley, B. W. Ellis \& H. Dudley. (1977). Sleep deprivation in patients undergoing operation: a factor in the stress of surgery. British Medical Journal, 2, 1521-1522.

Onen, S. H., F. Onen, P. Courpron \& C. Dubray. (2005). How pain and analgesics disturb sleep. Clinical Journal Of Pain, 21, 422-431. 
Ou slander, J. G., B. R. Connell, D. L. Bliw ise, Y. Endeshaw, P. Griffiths \& J. F. Schnelle. (2006). A nonpharmacological intervention to improve sleep in nursing home patients: results of a controlled clinical trial. Journal of A merican Geriatric Society, 54, 38-47.

Page, M. S., A. M. Berger \& L. B. Johnson. (2006). Putting evidence in to practice: Evidence-based interventions for sleep-wake disturbances. Clinical Journal of Oncology Nursing, 10, 753-767.

Public-health-resource-unit. (1993). Critical Appraisal Skills Programme (CASP). Public health resource unit.

Richard s, K. (1987). Techniques for measurement of sleep in critical care. Focus on Critical Care, 14, 34-40.

Richard s, K. (1998). Effect of a back massage and relaxation intervention in sleep in critically ill patients. American Journal of Critical Care, 7, 288-299.

Richard s, K., C. Nagel, M. Markie, J. Elwell \& C. Barone. (2003). Use of complementary and alternative therapies to promote sleep in critically ill patients. Critical Care Nursing Clinics of North A merica, 15, 329-340.

Richard son, S. (2003). Effects of relaxation and imagery on the sleep of critically ill adults. Dimensions of Critical Care Nursing, 22, 182-190.

Robinson, S. B., T. Weitzel \& L. Henderson. (2005). The sh-h-h-h project: non pharmacological intervention. Holistic Nursing Practice, 19, 263-266.

Schnelle, J. F., C. A. Alessi, N. R. Al-Samarrai, R. D. Fricker \& J. G. Ou slander. (1999). The nursing home at night: effects of an intervention on noise, light and sleep. Journal of A merican Geriatric Society, 47, 430-438.

Simeit, R., R. Deck \& B. Conta-Marx. (2004). Sleep management training for cancer patients with in somnia. Supportive Care in Cancer, 12, 176-183.

Smith, M. C., J. Kemp, L. Hemphill \& C. P. Vojir. (2002). Outcomes of therapeutic massage for hospitalized cancer patients. Journal of Nursing Scholarship, 34, 257262.

Snyder-Halpern, R. \& J. A. Verran. (1987). Instrumentation to describe subjective sleep characteristics in healty subjects. Research in Nursing and Health, 10, 155163.

Soden, K., K. Vincent, S. Craske, C. Lucas \& S. Ashley. (2004). A randomized controlled trial of aromatherapy massage in a hospice setting. Palliative Medicine, 18, 87-92.

Sold atos, C. R., D. G. Dikeos \& T. J. Paparrrigopoulos. (2000). Athens Insomnia Scale: validation of an instrument based on ICD-10 criteria. Journal of Psychosomatic Research, 48, 555-560.

Southwell, M. \& G. Wistow . (1995). Sleep in hospitals at night: are patients' needs being met. Journal of Advanced Nursing, 1101-1109.

Spiegel, K., R. Leproult \& E. V. Cauter. (1999). Impact of sleep dept on metabolic and end ocrine function. The Lancet, 354, 1435-1439.

Stone, K. L., K. E. Ensrud \& S. Ancoli-Israel. (2008). Sleep, in somnia and falls in eld erly patients. Sleep Medicine, 9, 18-22.

Suen, L. K. P., T. K. S. Wong \& A. W. N. Leung. (2002). Effectiveness of auricular therapy on sleep promotion in the elderly. American Journal of Chinese Medicine, 30, 429-449.

Tranmer, J. E., J. Minard, L. A. Fox \& L. Rebelo. (2003). The sleep experience of medical and surgical patients. Clinical Nursing Research, 12, 159-173. 
Walder, B., D. Francoioli, J. J. Meyer, M. Lancon \& J. A. Romand . (2000). Effects of guidelines implementation in a surgical intensive care unit to control nighttime light and noise levels. Critical care Medicine, 28, 2242-2247.

Williamson, J. W. (1992). The effect of ocean sounds on sleep after coronary artery by pass graft surgery. American Journal of Critical Care 1, 91-97.

Willman, A., P. Stoltz \& C. Bahtsevani. (2006). Eviden sbaserad omvårdnad - en bro mellan forskning och klinisk verksamhet [Evidence-based nursing - a bridge between research and clinical nursing] Stud entlitteratur: Lund.

Wills, E. (2007a). Grand nursing theories based on human needs. In M. McEwen \& E. Wills (Eds.), Theoretical basis for nursing. Lippincott William s \& Wilkin s: Philadelphia.

Wills, E. (2007b). Grand nursing theories based on interactive process. In M. McEwen \& E. Wills (Ed s.), Theoretical basis for nursing. Lippincott Williams \& Wilkins: Philad elphia.

Zimmerman, L., J. Nieveen, S. Barnason \& M. Schmaderer. (1996). The effects of music interventions on postoperative pain and sleep in coronary artery bypass graft (CABG) patien ts. Sholary of Inquiry Nursing Practice, 10, 153-170. 
Table 1. The literature search.

\begin{tabular}{|c|c|c|c|c|}
\hline & $\begin{array}{l}\text { Review/meta- } \\
\text { analysis }\end{array}$ & $\begin{array}{l}\text { RCT/quasi- } \\
\text { experimental }\end{array}$ & Total & $\begin{array}{l}\text { Remaining } \\
\text { search hits }\end{array}$ \\
\hline Search hits & 7 & 45 & 52 & \\
\hline $\begin{array}{l}\text { No abstract } \\
\text { available }\end{array}$ & 1 & 3 & 4 & 48 \\
\hline $\begin{array}{l}\text { Paper could } \\
\text { not be } \\
\text { retrieved } \\
\text { from library } \\
\text { or internet }\end{array}$ & - & 5 & 5 & 43 \\
\hline $\begin{array}{l}\text { Paper did } \\
\text { not fulfil } \\
\text { inclusion } \\
\text { criteria }\end{array}$ & $\begin{array}{l}1 \\
\text { Reasons: } \\
\text { The study is not } \\
\text { carried out in a health } \\
\text { care setting. }\end{array}$ & $\begin{array}{l}10 \\
\text { Reasons: } \\
\text { The study is not } \\
\text { carried out in a health } \\
\text { care setting. }\end{array}$ & 11 & 32 \\
\hline $\begin{array}{l}\text { Paper } \\
\text { excluded } \\
\text { after } \\
\text { abstract was } \\
\text { read }\end{array}$ & $\begin{array}{l}3 \\
\text { Reasons: } \\
\text { All studies included } \\
\text { did not correspond } \\
\text { with the aim of this } \\
\text { review. }\end{array}$ & $\begin{array}{l}5 \\
\text { Reasons: } \\
\text { The paper does not } \\
\text { correspond with our } \\
\text { aim. }\end{array}$ & 8 & 25 \\
\hline $\begin{array}{l}\text { Paper } \\
\text { excluded } \\
\text { after } \\
\text { reading }\end{array}$ & $\begin{array}{l}1 \\
\text { Reasons: } \\
\text { The approach was not } \\
\text { systematic. }\end{array}$ & $\begin{array}{l}3 \\
\text { Reasons: } \\
\text { The paper does not } \\
\text { correspond with our } \\
\text { aim. }\end{array}$ & 4 & 21 \\
\hline $\begin{array}{l}\text { Paper } \\
\text { excluded } \\
\text { after critical } \\
\text { appraisal }\end{array}$ & $\begin{array}{l}1 \\
\text { Reasons: } \\
\text { The findings of the } \\
\text { study were not } \\
\text { elusive. }\end{array}$ & $\begin{array}{l}11 \\
\text { Reasons: } \\
\text { The description of } \\
\text { procedure was vague, } \\
\text { the design was not } \\
\text { reliable, large drop- } \\
\text { out making results } \\
\text { uncertain. }\end{array}$ & 12 & 9 \\
\hline
\end{tabular}


Figure 1. Description of GRADE assessment.

Criteria for assessing grade of evidence

Study design

Randomized trial=high

Observational study=low

Any other evidence=very low

Decrease grade if:

There are limitations in study quality $(-1$ or -2$)$

There is important inconsistency $(-1)$

There is uncertainty about the directness $(-1$ or -2$)$

There is imprecise/sparse data (-1)

There is a high probability of reporting bias $(-1)$

Increase grade if:

Strong evidence of association $(+1)$

Very strong evidence of association $(+2)$

All plausible confounders would have reduced the effect $(+1)$

Source: "Grading quality of evidence and strength of recommendations", BMJ, 2004. 
Table 2. The excluded articles.

\begin{tabular}{|c|c|c|c|}
\hline $\begin{array}{l}\text { Author } \\
\text { Year }\end{array}$ & Methods & Intervention & Reasons for exclusion \\
\hline $\begin{array}{l}\text { Ancoli-Israel et al. } \\
2002\end{array}$ & RCT & Bright light therapy & $\begin{array}{l}\text { No description of randomization process, group sizes or } \\
\text { number of control groups. }\end{array}$ \\
\hline $\begin{array}{l}\text { Cmiel et al. } \\
2004\end{array}$ & Clinical-study/ descriptive & Sleep hygiene & $\begin{array}{l}\text { No control group, no sleep measures, unsatisfactory } \\
\text { description of procedure. }\end{array}$ \\
\hline $\begin{array}{l}\text { Ho et al. } \\
2002\end{array}$ & Quasi-experimental & Bright light therapy & No control group, no recognized outcome measures. \\
\hline $\begin{array}{l}\text { Koyama et al. } \\
1999\end{array}$ & Observational study & Bright light therapy & $\begin{array}{l}\text { Results based on observations of six individuals, no } \\
\text { recognized outcome measures. }\end{array}$ \\
\hline $\begin{array}{l}\text { McDowell et al. } \\
1998\end{array}$ & Quasi-experimental & $\begin{array}{l}\text { Patients got to choose from seven different interventions and } \\
\text { noise was reduced. }\end{array}$ & $\begin{array}{l}\text { No account of the number of persons who got a certain } \\
\text { intervention, no report on the outcome. No baseline } \\
\text { measures or control group. }\end{array}$ \\
\hline $\begin{array}{l}\text { Ouslander et al. } \\
2006\end{array}$ & $\mathrm{RCT}$ & Sleep hygiene & $\begin{array}{l}\text { Randomization at group level, no explanation of group } \\
\text { allocation, no report concerning drop-outs. }\end{array}$ \\
\hline $\begin{array}{l}\text { Richards } \\
2003\end{array}$ & Systematic review & Complementary/alternative therapies & $\begin{array}{l}\text { The result of the systematic review was mixed with } \\
\text { findings of not included studies, making interpretation } \\
\text { of outcomes impossible. }\end{array}$ \\
\hline $\begin{array}{l}\text { Robinson et al. } \\
2005\end{array}$ & Quasi-experimental & Patients got to choose from several different interventions & $\begin{array}{l}\text { No account of the number of persons who got a certain } \\
\text { intervention, no report on the outcome. }\end{array}$ \\
\hline $\begin{array}{l}\text { Schnelle et al. } \\
1999\end{array}$ & RCT & Sleep hygiene & $\begin{array}{l}\text { Randomization at group level, no explanation of group } \\
\text { allocation, no report concerning drop-outs. }\end{array}$ \\
\hline $\begin{array}{l}\text { Simeit et al. } \\
2004\end{array}$ & Quasi-experimental & Relaxation & $\begin{array}{l}\text { No randomization, possible bias due to sleep hygiene } \\
\text { advices given to all participants in the beginning of the } \\
\text { study. }\end{array}$ \\
\hline $\begin{array}{l}\text { Smith et al. } \\
2002\end{array}$ & Quasi-experimental & Massage & $\begin{array}{l}\text { Small sample } n=41 \text {, drop outs } n=18 \text {, making results } \\
\text { very uncertain. }\end{array}$ \\
\hline $\begin{array}{l}\text { Walder et al. } \\
2000\end{array}$ & Observational study & Sleep hygiene & $\begin{array}{l}\text { Convenience sample, small sample } n=17 \text {, no report } \\
\text { concerning drop-outs. No direct measures of sleep - } \\
\text { just light and noise. }\end{array}$ \\
\hline
\end{tabular}


Table 3. Articles included in the review.

\begin{tabular}{|c|c|c|c|c|c|c|c|}
\hline Study & Design & Measures & $\begin{array}{l}\text { Study population/ } \\
\text { Setting }\end{array}$ & Intervention & Control condition & Outcome & $\begin{array}{l}\text { Quality } \\
\text { (CASP) }\end{array}$ \\
\hline $\begin{array}{l}\text { Alessi et al. } \\
2005 \\
\text { USA }\end{array}$ & RCT & Actigraph & $\begin{array}{l}\mathrm{n}=118 \\
\text { Drop-out: } 10 \\
\text { Mean age: not reported? } \\
\text { Setting: Nursing homes }\end{array}$ & $\begin{array}{l}\text { Sleep hygienic protocol; keep patients out of bed during } \\
\text { day time, sunlight exposure, bed time routines and } \\
\text { reduction of light and noise levels. Intervention lasted for } 5 \\
\text { days. } n=58\end{array}$ & $\begin{array}{l}\text { Care as usual } \\
n=56\end{array}$ & $\begin{array}{l}\text { Day time sleep } \downarrow \\
\text { TST } \leftrightarrow \\
\text { MSA } \leftrightarrow\end{array}$ & $\begin{array}{l}\text { High } \\
\text { High generalizability, relevant } \\
\text { outcome measures, well } \\
\text { described procedure. }\end{array}$ \\
\hline $\begin{array}{l}\text { Kim et al. } \\
2004 \\
\text { Korea }\end{array}$ & RCT & $\begin{array}{l}\text { MQ } \\
\text { ISI } \\
\text { AIS }\end{array}$ & $\begin{array}{l}n=32 \text { (post-stroke patients) } \\
\text { Drop-out:2 } \\
\text { Mean age: } 65,1 \text { years in } \\
\text { intervention group, } 68,3 \text { years in } \\
\text { control group. } \\
\text { Setting: Stroke Centre }\end{array}$ & $\begin{array}{l}\text { Intradermal acupuncture, using four needles on Shen-Men } \\
\text { and Nei-Kuan bilateral. The intervention lasted for } 2 \text { days. } \\
\mathrm{n}=15\end{array}$ & $\begin{array}{l}\text { Sham acupuncture } \\
\mathrm{n}=15\end{array}$ & $\begin{array}{l}\text { TST } \uparrow \\
\text { SQ } \uparrow \\
\text { Condition upon awakening } \uparrow\end{array}$ & $\begin{array}{l}\text { Medium } \\
\text { High generalizability } \\
\text { considering sample, relevant } \\
\text { outcome measures, } \\
\text { intervention demands skills, } \\
\text { small size of study }\end{array}$ \\
\hline $\begin{array}{l}\text { LaReau et al. } \\
2008 \\
\text { USA }\end{array}$ & RCT (pilot) & RCSQ & $\begin{array}{l}n=70 \\
\text { Drop-out: } 11 \\
\text { Mean age: } 79,6 \text { years } \\
\text { Setting: Adult medical unit \& } \\
\text { cardiology unit. }\end{array}$ & $\begin{array}{l}\text { Sleep hygiene protocol consisting of personal hygiene, } \\
\text { room temperature adjustment, noise- and light control, } \\
\text { relaxation techniques and clustering of nursing } \\
\text { interventions. The study lasted for } 16 \text { weeks. } n=29\end{array}$ & $\begin{array}{l}\text { Usual night time care } \\
\mathrm{n}=30\end{array}$ & $\begin{array}{l}\text { SQ个 (ns) } \\
\text { MSA } \text { (ns) } \\
\text { Sleep medication } \downarrow\end{array}$ & $\begin{array}{l}\text { Medium } \\
\text { High generalizability, risk of } \\
\text { bias at data collection, } \\
\text { description of procedure is } \\
\text { sparse }\end{array}$ \\
\hline $\begin{array}{l}\text { Richards } \\
1998 \\
\text { USA }\end{array}$ & RCT & PSG & $\begin{array}{l}\mathrm{n}=71 \text { (all men) } \\
\text { Drop-out: } 2 \\
\text { Mean age: Not reported (55-79 } \\
\text { years) } \\
\text { Setting: Intensive care ward }\end{array}$ & $\begin{array}{l}\text { Group } 1 \text { got back massage } 6 \text { min before going to bed, } \\
\text { group } 2 \text { was educated in relaxation and got a } 7,5 \text { min tape } \\
\text { with muscle relaxation, mental imagery and background } \\
\text { music at bedtime. } n=24 / n=28\end{array}$ & $\begin{array}{l}\text { Care as usual and a } 6 \text { min rest } \\
\text { before going to bed. } \\
n=17\end{array}$ & $\begin{array}{l}\text { Massage : } \\
\text { SQ } \uparrow \\
\text { TST } \uparrow \\
\text { SL } \downarrow \\
\text { REM-sleep } \uparrow \\
\text { Relax/Music/Imagery: } \\
\text { SQ } \uparrow \\
\text { No sign differences between groups. }\end{array}$ & $\begin{array}{l}\text { Medium } \\
\text { Limited generalizability, small } \\
\text { groups, relevant outcome } \\
\text { measures }\end{array}$ \\
\hline $\begin{array}{l}\text { Richardson } \\
2003 \\
\text { USA }\end{array}$ & RCT & $\begin{array}{l}\text { VSH-Sleep } \\
\text { Scale }\end{array}$ & $\begin{array}{l}\mathrm{n}=36 \\
\text { Drop-out: No drop out } \\
\text { Mean age: } 58,4 \text { years } \\
\text { Setting: Intensive care ward. }\end{array}$ & $\begin{array}{l}\text { Effect of relaxation and mental imagery on sleep. The } \\
\text { session was delivered in-person. The intervention lasted } \\
\text { for } 2 \text { days. }\end{array}$ & Care as usual. & $\mathrm{SQ} \uparrow(\mathrm{ns})$ & $\begin{array}{l}\text { Medium } \\
\text { High generalizability, relevant } \\
\text { outcome measure, small } \\
\text { sample }\end{array}$ \\
\hline $\begin{array}{l}\text { Soden et al. } \\
2004 \\
\text { UK }\end{array}$ & RCT & $\begin{array}{l}\text { VHS-Sleep } \\
\text { Scale }\end{array}$ & $\begin{array}{l}n=42 \text { (patients with advanced } \\
\text { cancer) } \\
\text { Drop-out: } 6 \\
\text { Mean age: } 73 \text { years } \\
\text { Setting: Hospice setting. }\end{array}$ & $\begin{array}{l}\text { Patients randomized to aromatherapy and massage or } \\
\text { massage only, received } 30 \text { min back massage once a week. } \\
\text { Intervention lasted for } 4 \text { weeks. }\end{array}$ & Control group had no massage & $\begin{array}{l}\text { Aromatherapy and massage: } \\
\text { VHS-tot. score } \leftrightarrow \text {, a tendency of } \\
\text { improved tot. sleep score. } \\
\text { Massage: } \\
\text { VHS-tot. score } \uparrow\end{array}$ & $\begin{array}{l}\text { Medium } \\
\text { Distinct design and procedure, } \\
\text { relevant outcome measure, } \\
\text { small sample, short-term } \\
\text { outcome }\end{array}$ \\
\hline $\begin{array}{l}\text { Suen et al. } \\
2002 \\
\text { Hong Kong, China }\end{array}$ & RCT & $\begin{array}{l}\text { Actigraph } \\
\text { Sleep } \\
\text { questionnaire } \\
\text { Sleep diary } \\
\text { (filled in by } \\
\text { staff) }\end{array}$ & $\begin{array}{l}n=120 \\
\text { Drop-out: } 19 \\
\text { Mean age: not reported }(\geq 60 \\
\text { years) } \\
\text { Setting: Hostels for elderly. }\end{array}$ & $\begin{array}{l}\text { Experimental group used magnetic pearls. The } \\
\text { intervention lasted for } 3 \text { weeks. } n=52\end{array}$ & $\begin{array}{l}\text { Control group } 1 \text { used Junci } \\
\text { Medulla, a dried stem of a plant, } \\
\text { assumed not to have therapeutic } \\
\text { effect in auricular therapy. } \\
\text { Control group } 2 \text { used Semen } \\
\text { Vaccariae, commonly used for } \\
\text { auricular taping. } n=49\end{array}$ & $\begin{array}{l}\text { TST } \uparrow \\
\text { SE } \uparrow \\
\text { No difference between the two } \\
\text { control groups. }\end{array}$ & $\begin{array}{l}\text { Medium } \\
\text { High generalizability, relevant } \\
\text { outcome measures, description } \\
\text { of procedure is sparse }\end{array}$ \\
\hline $\begin{array}{l}\text { Williamson } \\
1992 \\
\text { USA }\end{array}$ & RCT & RCSQ & $\begin{array}{l}\mathrm{n}=60 \text { (CABG patients) } \\
\text { Drop-out: } 4 \\
\text { Mean age: } 58 \text { years } \\
\text { Setting: Progressive care area, after } \\
\text { transfer from the intensive care } \\
\text { unit. }\end{array}$ & $\begin{array}{l}\text { Effect of common nature sounds on sleep. A tape was } \\
\text { played from 8:30 pm. or } 9 \text { pm. and was played through the } \\
\text { night for } 3 \text { nights in a row. }\end{array}$ & $\begin{array}{l}\text { Controls had no corresponding } \\
\text { noise at night. }\end{array}$ & $\begin{array}{l}\mathrm{SD} \uparrow \\
\mathrm{SL} \downarrow \text { (ns) } \\
\mathrm{SQ} \uparrow\end{array}$ & $\begin{array}{l}\text { Medium } \\
\text { Limited generalizability, } \\
\text { relevant outcome measures }\end{array}$ \\
\hline $\begin{array}{l}\text { Zimmerman et al. } \\
1996 \\
\text { USA }\end{array}$ & RCT & RCSQ & $\begin{array}{l}n=96 \text { (CABG patients) } \\
\text { Drop-out: no drop out } \\
\text { Mean age: } 67 \text { years } \\
\text { Setting: Post intensive care in } \\
\text { hospital }\end{array}$ & $\begin{array}{l}\text { Soothing music or an instrumental music video. Group } 1 \\
\text { (music therapy), Group } 2 \text { (music videos). The intervention } \\
\text { lasted for } 2 \text { days. }\end{array}$ & $\begin{array}{l}\text { Controls rested before going to } \\
\text { bed. }\end{array}$ & 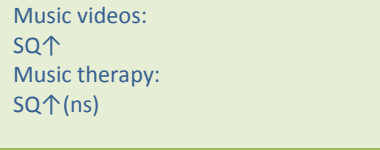 & $\begin{array}{l}\text { High } \\
\text { Limited generalizability, } \\
\text { relevant outcome measures, } \\
\text { satisfying description of } \\
\text { procedure. }\end{array}$ \\
\hline
\end{tabular}

Abbreviations in the table: AIS= Athens Insomnia Scale, ISI= Insomnia Severity Index, MQ= Morning Questionnaire, RCSQ= Richards Campbell Sleep Questionnaire,VSH=Verran \& Snyder-Helpern Sleep Scale, PSG=polysomnography 
Table 4. Strength of evidence for the nursing interventions found in the review.

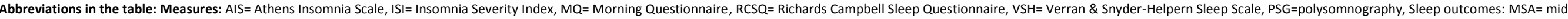
sleep awakenings, $\mathrm{SE}=$ sleep efficiency (time spent in bed/ time asleep), SL= sleep latency, TST=total sleep time

\begin{tabular}{|c|c|c|c|c|c|c|c|}
\hline Intervention & Measure & Studies & $\begin{array}{l}\text { Size experimental } \\
\text { group }\end{array}$ & $\begin{array}{l}\text { Size } \\
\text { control } \\
\text { group }\end{array}$ & $\begin{array}{l}\text { Post treatment } \\
\text { effects }\end{array}$ & $\begin{array}{l}\text { Scientific quality } \\
\text { (CASP) }\end{array}$ & $\begin{array}{l}\text { Evidence } \\
\text { of intervention }\end{array}$ \\
\hline \multirow[t]{2}{*}{ Sleep hygiene } & Actigraph & Alessi et al. 2005 & $\mathrm{n}=58$ & $\mathrm{n}=56$ & $\begin{array}{l}\text { TST Cohen's } \mathrm{d}=0.32 \\
\text { MSA Cohen's } \mathrm{d}=0.006\end{array}$ & High & $\begin{array}{l}\text { Evidence grade: Low } \\
\text { Design: High }\end{array}$ \\
\hline & RCSQ & LaReau et al. 2008 & $\mathrm{n}=29$ & $\mathrm{n}=30$ & $\begin{array}{l}\text { TST Cohen's d }=0.05 \\
\text { MSA p-value }=.19\end{array}$ & Medium & $\begin{array}{l}\text { Inconsistency:-1 (different measures) } \\
\text { Indirectness: no }\end{array}$ \\
\hline \multirow{2}{*}{$\begin{array}{l}\text { Music, natural } \\
\text { sounds and } \\
\text { vision }\end{array}$} & RCSQ & Williamson 1992 & $\mathrm{n}=26$ & $\mathrm{n}=30$ & RCSQ(tot. score) $\mathrm{p}$-value $=.002$ & Medium & $\begin{array}{l}\text { Evidence grade: Very low } \\
\text { Design: High }\end{array}$ \\
\hline & RCSQ & $\begin{array}{l}\text { Zimmerman et al. } \\
1996\end{array}$ & $\begin{array}{l}\mathrm{n}=32 \text { (video) } \\
\mathrm{n}=32 \text { (music) }\end{array}$ & $\mathrm{n}=32$ & $\begin{array}{l}\text { Music video: } \\
\text { RCSQ(tot. score) Cohen's d=0.7 } \\
\text { Music: } \\
\text { RCSQ(tot. score) Cohen's d=0.5 }\end{array}$ & High & $\begin{array}{l}\text { Quality:-1 } \\
\text { Inconsistency:-1 (inconsistent data on RCSQ score) } \\
\text { Indirectness:-1 (tested in only one specific patient } \\
\text { category) }\end{array}$ \\
\hline \multirow[t]{2}{*}{$\begin{array}{l}\text { Stimulation of } \\
\text { acupoints }\end{array}$} & $\begin{array}{l}\text { AIS } \\
\text { ISI } \\
\text { MQ }\end{array}$ & Kim et al. 2004 & $\mathrm{n}=15$ & $\mathrm{n}=15$ & $\begin{array}{l}\text { SL Cohen's d }=0.44 \\
\text { TST Cohen's d }=1.02 \\
\text { ISI (tot. score) Cohen's d=1.34 } \\
\text { AIS(tot. score) Cohen's d }=1.11\end{array}$ & Medium & $\begin{array}{l}\text { Evidence grade: Very low } \\
\text { Design: High } \\
\text { Quality:-2 } \\
\text { Inconsistency:-1 (different measures) } \\
\text { Indirectness: no }\end{array}$ \\
\hline & Actigraph & Suen et al. 2002 & $\mathrm{n}=52$ & $\begin{array}{l}\mathrm{n}=49 \\
(2 \text { contr. } \\
\text { groups) }\end{array}$ & $\begin{array}{l}\text { SE Cohen's d }=0.64-0.88 \\
\text { SL Cohen's d=0.17-0.5 } \\
\text { MSA Cohen's d=0.47-0.85 }\end{array}$ & Medium & \\
\hline \multirow[t]{2}{*}{ Relaxation } & VSH-Scale & Richardson 2003 & $\mathrm{n}=16$ & $\mathrm{n}=20$ & Sleep score $=($ MSA + SD $) p=.425$ & Medium & $\begin{array}{l}\text { Evidence grade: Very low } \\
\text { Design: High }\end{array}$ \\
\hline & PSG & Richards 1998 & $\mathrm{n}=28$ & $\mathrm{n}=17$ & $\begin{array}{l}\text { SE Cohen's } d=0.34 \\
\text { SL Cohen's } d=-0.07 \\
\text { TST Cohen's } d=0.17 \\
\text { MSA Cohen's } d=0.05\end{array}$ & Medium & $\begin{array}{l}\text { Quality:-2 } \\
\text { Inconsistency:-1 (different measures) } \\
\text { Indirectness:-2 (tested in intensive care, mostly in } \\
\text { males) }\end{array}$ \\
\hline \multirow[t]{2}{*}{ Massage } & PSG & Richards 1998 & $\mathrm{n}=24$ & $\mathrm{n}=17$ & $\begin{array}{l}\text { SE Cohen's d }=0.77 \\
\text { SL Cohen's d }=0.22 \\
\text { TST Cohen's } d=0.75 \\
\text { MSA Cohen's d }=0.26\end{array}$ & Medium & $\begin{array}{l}\text { Evidence grade: Very low } \\
\text { Design: High } \\
\text { Quality:-2 } \\
\text { Inconsistency: -1 } \\
\text { Indirectness: no }\end{array}$ \\
\hline & VSH-scale & Soden et al. 2004 & $\mathrm{n}=13$ & $\mathrm{n}=13$ & VSH (tot. score) $\mathrm{p}=0.02$ & Medium & \\
\hline Aromatherapy & VSH-scale & Soden et al. 2004 & $\mathrm{n}=16$ & $\mathrm{n}=13$ & VSH (tot. score) $\mathrm{p}=0.4$ & Medium & $\begin{array}{l}\text { Evidence grade: Very low } \\
\text { Design: High } \\
\text { Quality: -1 } \\
\text { Inconsistency: no } \\
\text { Indirectness:-1 (tested in a small sample) }\end{array}$ \\
\hline
\end{tabular}


